\title{
Influence of synthesis parameters of mesocellular silica foams doped by nickel on methane reforming by $\mathrm{CO}_{2}$
}

\author{
O.Daoura, M. Boutros. \\ Laboratoire Chimie-physique des matériaux (LCPM/PR2N) \\ Lebanese University, Faculty of Sciences II (UL/FSII) \\ Beirut, Lebanon
}

\author{
O.Daoura, F.Launay, P. Massiani. \\ Laboratoire de Réactivité de Surface (LRS) \\ Université Pierre et Marie Curie (UPMC) \\ Paris, France
}

\author{
N. EL Hassan \\ Chemical engineering department \\ University Of Balamand (UOB) \\ Koura, Lebanon
}

\begin{abstract}
New catalysts based on $\mathrm{Ni}(0)$ dispersed onto mesocellular silica foams (MCF) were prepared for Dry Reforming of Methane (DRM). Different synthesis methods of MCF supports (with and without using $\mathrm{NH}_{4} \mathrm{~F}$ or $n$-butanol) were tested in order to study the influence of the textural properties of the support on the catalytic performances of the catalysts. In all cases, nickel was incorporated using the double solvents method. The resulting calcined materials were characterized by $\mathrm{N}_{2}$ sorption, X-Ray diffraction (XRD) and transmission electron microscopy. Their reducibility was tested by temperature-programmed reduction (TPR). Interestingly, particularly large specific surfaces, pores diameters and pores volumes were observed when $\mathrm{NH}_{4} \mathrm{~F}$ was added to the synthesis gel $(\mathrm{MCF}(\mathrm{N})$ materials). The corresponding Ni$\operatorname{MCF}(\mathrm{N})$ catalysts were shown to be the most attractive among other prepared samples with respect to their performances in DRM.
\end{abstract}

Keywords - Methane reforming ; Nickel ; Nanoparticles ; Mesocellular foams.

\section{INTRODUCTION}

In 1999, siliceous mesocellular foams (MCF) were prepared for the first time by combining self-assembly processes through a $\left(\mathrm{S}^{0} \mathrm{H}^{+}\right)\left(\mathrm{X}^{-} \mathrm{I}^{+}\right)$pathway used for SBA-15 synthesis and pore swelling with organic molecules [1]. Preferentially solubilized in the core of micelles, these molecules lead, as expected, to an increase of the pore volume but also to a modification of the porosity organization [2]. Since, resulting MCF with large spherical cell sizes up to 40 $\mathrm{nm}, 3 \mathrm{D}$ interconnected pore system and large pore volumes [3] have shown great potential as supports for drug molecule release [1] or for the design of heterogeneous catalysts through the incorporation of enzymes/proteins [4], metal nanoparticles [5] to name only a few. Up to now, various synthesis methods of MCF have been reported in the literature. Among them, the challenge is to obtain complex mesophases using a fourcomponent microemulsion (surfactant/co surfactant/oil/water) as a template [6]. Several examples of co-surfactant / oil combinations have been described in the literature. Among the molecules added, n-butanol $(n-\mathrm{BuOH})$ is known to act both as a co-solvent and co-surfactant in block copolymer-water systems. In other terms, $n$ - $\mathrm{BuOH}$ stabilizes the hydrophilichydrophobic interfaces acting on the micellar surface curvature and on the total volume of the hydrophobic chains of the block copolymer [7].

In the present contribution, MCF doped by $5 \mathrm{wt} \%$ of nickel was used for the first time as a catalyst for Dry Reforming of Methane (DRM). Studies on DRM present both scientific and industrial interest. This reaction consists in transforming two abundantly available greenhouse gases $\left(\mathrm{CH}_{4}\right.$ and $\mathrm{CO}_{2}$ ) to produce industrially important syngas (a mixture of $\mathrm{CO}$ and $\mathrm{H}_{2}$ ). The latter is usable in the synthesis of a broad range of higher alkanes through Fischer-Tropsch synthesis [8]. However, DRM is accompanied by secondary reactions such as Methane Decomposition (MD), Reverse Water Gas Shift (RWGS) and Boudouard reaction (BD) [9]. To limit them, to favor the endothermic DRM reaction and to reach high equilibrium conversion of $\mathrm{CH}_{4}$ and $\mathrm{CO}_{2}$ to $\mathrm{H}_{2}$ and $\mathrm{CO}$, operating temperatures of $800-1000^{\circ} \mathrm{C}$ are usually required. This also minimizes side reactions [8]. For these reasons, inexpensive catalysts affording the expected $\mathrm{CO} / \mathrm{H}_{2}$ molar ratio are highly desired in order to lower the operating conditions.

In this work, four types of MCF materials with different textural properties were synthetized with the aim to select the most convenient supports for DRM catalysts preparation. The latter were obtained after deposition of $5 \mathrm{wt} \% \mathrm{Ni}$ using the double solvents method [10]. The porosity and the structure of the solids as well as the nickel dispersion were analyzed. The catalysts were tested in dry reforming of methane after reduction. Their catalytic performances in terms of conversions, products selectivity and stability were analyzed and compared to thermodynamic curves simulated by the HSC program considering or not carbon formation and similar reaction conditions. 


\section{EXPERIMENTAL PART}

\section{A. Catalysts preparation}

A typical synthesis of MCF, as described by Widyaningrum et al [11], was used first. It consisted in fully dissolving $4.0 \mathrm{~g}$ of Pluronic (P123) triblock copolymer $\left(\mathrm{EO}_{20} \mathrm{PO}_{70} \mathrm{EO}_{20}\right)$ in a mixture of $\mathrm{HCl}(20 \mathrm{~mL}, 37 \%)$ and distilled water $(120 \mathrm{~mL})$ at $40^{\circ} \mathrm{C}$, then adding dropwise $4.0 \mathrm{~g}$ of trimethylbenzene (TMB) as swelling agent, under vigorous stirring. To form a microemulsion, the suspension was stirred for $2 \mathrm{~h}$ then tetraethylorthosilicate (TEOS, $9 \mathrm{~mL}$ ) was added dropwise and stirring was continued for $20 \mathrm{~h}$ at the same temperature. The solution was next transferred in an autoclave and submitted to a hydrothermal treatment at $100^{\circ} \mathrm{C}$ for $24 \mathrm{~h}$. The resulting suspension was finally filtered and the solid was washed, dried and calcined under air flow at $550^{\circ} \mathrm{C}$ for $5 \mathrm{~h}$ (heating rate $1^{\circ} \mathrm{C} \cdot \mathrm{min}^{-1}$ ). The obtained solid was named MCF. Similar syntheses conditions were used to prepare sample $\mathrm{MCF}(\mathrm{N})$, except for the addition of $48 \mathrm{mg}$ of $\mathrm{NH}_{4} \mathrm{~F}$ done just before the hydrothermal treatment. Also, two other MCF silica foam materials, i.e. $\mathrm{MCF}(\mathrm{B} 1)$ and $\mathrm{MCF}(\mathrm{B} 2)$, were prepared using n-butanol as a co-surfactant following the synthesis procedure proposed by X. Zhou et al [7]. The considered molar $n-\mathrm{BuOH} / \mathrm{TMB}$ ratio was equal to 2 , which corresponded to the addition of $2 \mathrm{~g}$ of $\mathrm{TMB}$ and $2.4 \mathrm{~g}$ of butanol for $\mathrm{MCF}(\mathrm{B} 1)$, and of 4 and $4.6 \mathrm{~g}$, respectively, in the case of MCF (B2). Both, surfactant and co-surfactant, were added together.

$\mathrm{Ni}-\mathrm{MCF}, \mathrm{Ni}-\mathrm{MCF}(\mathrm{N})$ and $\mathrm{Ni}-\mathrm{MCF}(\mathrm{B} 1)$ materials were obtained by the impregnation of the supports with a $\mathrm{Ni}^{2+}$ containing solution using the double solvents method. The used nickel precursor was $\mathrm{Ni}\left(\mathrm{NO}_{3}\right)_{2} \cdot 6 \mathrm{H}_{2} \mathrm{O}$ and the theoretical loading of $\mathrm{Ni}$ added was $5 \mathrm{wt} \%$. In details, the support $(1.0 \mathrm{~g})$ was suspended in $20 \mathrm{~mL}$ of $\mathrm{n}$-hexane. After that, the appropriate amount of nickel precursor dissolved in a volume of water set equal to the silica pore volume (as determined by $\mathrm{N}_{2}$ physisorption) was added dropwise. The impregnated solids were dried 3 days at room temperature then overnight at $60{ }^{\circ} \mathrm{C}$ then calcined at $550{ }^{\circ} \mathrm{C}$ under air for $2 \mathrm{~h}$.

\section{B. Catalysts characterisations}

The catalysts were characterized in terms of textural, structural, reducibility and morphological properties. By recording $\mathrm{N}_{2}$ adsorption-desorption isotherms on an ASAP 2020 (Micromeritics) apparatus the textural properties of solids were obtained. The samples were degassed, prior to experiments, under vacum for $2 \mathrm{~h}$ at $250^{\circ} \mathrm{C}$. The specific surface area values were obtained by using the BET equation. The pore diameters and specific pore volumes were calculated according to the BJH model. X-Ray Diffraction (XRD) data were recorded on a diffractometer X'Pert3 Powder (PANalytical, Netherlands) using $\mathrm{CuK} \alpha$ radiation. The average particle sizes were calculated from the Scherer equation: $D=K \lambda / \beta \cos \theta$, where $K$ is a constant $(K=0.9), \lambda=$ $1.5405 \AA, \beta$ is the full width at half maximum (FWHM) of the diffraction peaks and $\theta$ is the peak position. Temperature-
Programmed Reduction (TPR) done in a TPD/R/O instrument (Autochem 2920 Micromeritics apparatus) was used to inform on the nickel phase reducibility and on the interaction of the metal with the support. The catalysts $(50 \mathrm{mg})$ were placed on a quartz wool in a U-shaped quartz sample tube and heated from room temperature to $800^{\circ} \mathrm{C}$ at a rate of $10^{\circ} \mathrm{C} \cdot \mathrm{min}^{-1}$ under a gaseous mixture flow $\left(25 \mathrm{~mL} \cdot \mathrm{min}^{-1}\right)$ of $5 \% \mathrm{H}_{2}$ diluted in Ar. Before reaching the thermal conductivity detector (TCD), the gas flow was passed through an ice bath to remove any water product formed during reduction. Transmission Electron Microscopy (TEM) analyses were performed on a JEOL-2010 (LaB) microscope operating at $200 \mathrm{kV}$. Ethanol was used to suspend the powdered samples. The resulting mixtures were deposited on a copper grid coated with a porous carbon film, then ethanol was left to evaporate by drying in room atmosphere.

\section{Catalytic measurements}

The catalysts were tested in a PID ENG \& TECH Microactivity Effi Reactor. They were loaded into the reactor and reduced in situ at $650^{\circ} \mathrm{C}$ for $2 \mathrm{~h}\left(\right.$ rate $\left.10^{\circ} \mathrm{C} \cdot \mathrm{min}^{-1}\right)$ in a $5 \%$ $\mathrm{H}_{2} /$ Ar flow ( $\left.30 \mathrm{~mL} \cdot \mathrm{min}^{-1}\right)$ to form reduced nickel known to be the active phase in DRM. After this activation treatment, the temperature was cooled down to $200^{\circ} \mathrm{C}$ and dry reforming of methane was conducted under atmospheric pressure with $\mathrm{CH}_{4} / \mathrm{CO}_{2}=1: 1$ (diluted with Ar) and a total GHSV=36 $\mathrm{L} \cdot \mathrm{g}^{-1} \cdot \mathrm{h}^{-1}$ (100 mg of catalyst were used for each test). Good reproducibility of catalytic results under these conditions was obtained. For activity measurements, the reaction temperature was increased from $200^{\circ} \mathrm{C}\left(5^{\circ} \mathrm{C} \cdot \mathrm{min}^{-1}\right)$ up to $750^{\circ} \mathrm{C}$ followed by a decrease of temperature till $650^{\circ} \mathrm{C}$ which was maintained for $4 \mathrm{~h}$. The gaseous products were analyzed online by a micro GC Agilent $490 \mathrm{mGC}$. The conversions of methane (1) and of carbon dioxide (2), as well as the $\mathrm{H}_{2} / \mathrm{CO}$ ratios (3) were calculated as follows:

$$
\begin{aligned}
& \mathrm{CH}_{4} \text { conversion }(\%)=\frac{\mathrm{CH}_{4_{(i n)}}-\mathrm{CH}_{4_{(\mathrm{out})}}}{\mathrm{CH}_{4_{(\text {in })}}} \times 100 \\
& \mathrm{CO}_{2} \text { conversion }(\%)=\frac{\mathrm{Co}_{2_{(i n))}}-\mathrm{CO}_{2_{(\text {out })}}}{\mathrm{CO}_{2_{(\text {in })}}} \times 100 \\
& \mathrm{H}_{2} / \mathrm{CO}=\frac{\mathrm{H}_{2} \text { (out) }}{\mathrm{CO}_{(\text {out })}}
\end{aligned}
$$

where $\mathrm{CH}_{4 \text { (in) }}$ and $\mathrm{CH}_{4 \text { (out) }}$ (resp. $\mathrm{CO}_{2 \text { (in) }}$ and $\mathrm{CO}_{2}$ (out) are the initial and measured $\mathrm{CH}_{4}$ (resp. $\mathrm{CO}_{2}$ ) concentrations, respectively, whereas $\mathrm{H}_{2 \text { (out) }}$ and $\mathrm{CO}$ (out) are the measured products concentrations.

\section{RESULTS AND DISSCUTIONS}

\section{A. $\mathrm{N}_{2}$ physisorption}

$\mathrm{MCF}, \mathrm{MCF}(\mathrm{N}), \mathrm{MCF}(\mathrm{B} 1)$ and $\mathrm{MCF}(\mathrm{B} 2)$ supports present type IV isotherms (Fig. 1). The observed hysteresis loops (IUPAC) are typical of mesoporous materials. 


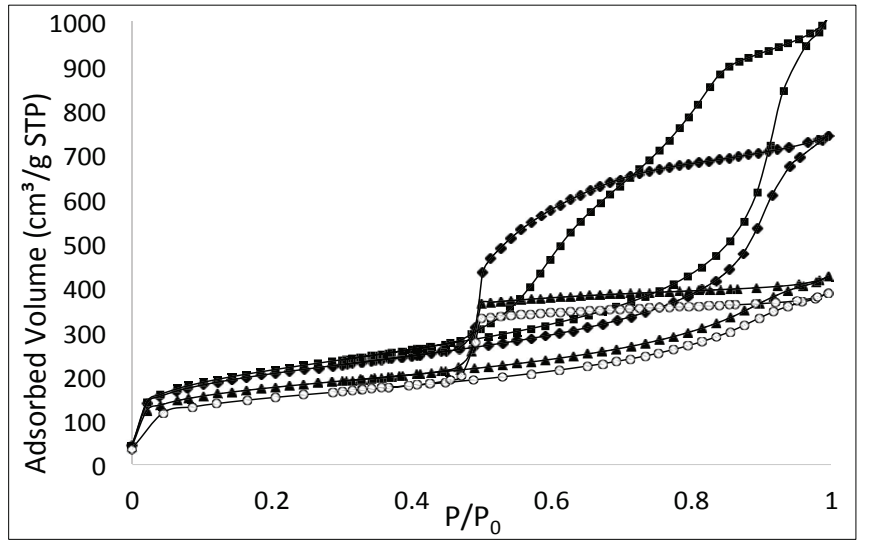

Fig. 1. $\mathrm{N}_{2}$ adsorption/desorption isotherms at $77 \mathrm{~K}$ of $\operatorname{MCF}(\mathrm{N})(\mathbf{\square}), \operatorname{MCF}(\bullet)$, $\operatorname{MCF}(\mathrm{B} 1)(\boldsymbol{\Delta})$ and $\mathrm{MCF}(\mathrm{B} 2)(\mathrm{o})$.

Most of them are of type $\mathrm{H} 2$ or $\mathrm{H} 1$, which is in agreement with the expected presence, in mesocellular foams, of connected cells and of pores with different shapes.

Addition of ammonium fluoride or n-butanol during synthesis led to a modification of the pores volumes and of the dimensions of the cells/pores, but not as much as for the specific surface area values (Table.1). On one hand, the influence of $\mathrm{NH}_{4} \mathrm{~F}$ has been already described as being related to the mineralizing effect of fluoride ions, giving improved structural organization and higher pore volume [3]. On the other hand, n-butanol used as a cosurfactant in $\mathrm{MCF}(\mathrm{B} 1)$ and $\operatorname{MCF}(\mathrm{B} 2)$ led to quite low volumes values which turned to be even smaller than those obtained with SBA-15.

TABLE I. TEXTURAL PROPERTIES OF SOLIDS BEFORE AND AFTER Ni IMPREGNATION

\begin{tabular}{|l|c|c|c|c|}
\hline \multirow{2}{*}{ Samples } & \multicolumn{4}{|c|}{ Textural properties } \\
\cline { 2 - 5 } & $\begin{array}{c}\boldsymbol{S}_{\text {BET }} \\
\left(\mathbf{m}^{2} / \mathbf{g}\right)\end{array}$ & $\begin{array}{c}\mathrm{V}_{\text {pores }} \\
\left(\mathbf{c m}^{3} / \mathbf{g}\right)\end{array}$ & $\begin{array}{c}\mathrm{D}_{\text {cells }} \\
(\mathbf{n m})\end{array}$ & $\begin{array}{c}\mathrm{D}_{\text {windows }} \\
(\mathbf{n m})\end{array}$ \\
\hline \hline MCF & 722 & 1.2 & 21 & 3.8 \\
\hline MCF(N) & 755 & 1.6 & 21 & 5 \\
\hline MCF(B1) & 696 & 0.7 & 15.2 & 4 \\
\hline \hline Ni-MCF(B2) & 687 & 0.6 & 7.0 & 4 \\
\hline Ni-MCF(N) & 490 & 1.14 & 21 & 4.6 \\
\hline Ni-MCF(B1) & 529 & 0.57 & 15.2 & 3.9 \\
\hline
\end{tabular}

Due to the similar textural features of $\operatorname{MCF}(\mathrm{B} 1)$ and $\operatorname{MCF}(\mathrm{B} 2)$, further work in this paper will be focused only on $\operatorname{MCF}(\mathrm{B} 1)$ amongst these two samples. The shapes of the $\mathrm{N}_{2}$ adsorption and desorption isotherms of the materials after impregnation of these supports with $5 \mathrm{wt} \% \mathrm{Ni}$ were similar to those before Ni addition, with type IV isotherms and $\mathrm{H} 2$ or $\mathrm{H} 1$ hysteresis loop (IUPAC) (Fig. 2). Nevertheless, the pores volumes and specific surface area decreased by 20 to $30 \%$ upon $\mathrm{Ni}$ insertion, the effect being the most pronounced in the case of Ni-MCF(N) (Table I). The diameter of the cells was retained in the case of $\mathrm{Ni}-\mathrm{MCF}(\mathrm{N})$ and $\mathrm{Ni}-\mathrm{MCF}(\mathrm{B} 1)$ samples but decreased a little bit, from 21 to $18 \mathrm{~nm}$, for Ni-MCF. On the other hand, windows dimensions were reduced only for $\operatorname{MCF}(\mathrm{N})$. However, further characterization is needed in order to correlate the decrease of the dimensions of the cells or windows with the preferential location of the $\mathrm{NiO}$ particles.

\section{B. X-Ray Diffraction (XRD)}

Wide angle XRD patterns of the calcined Ni-supports are shown in Fig. 3. In all cases, a broad peak at about $2 \theta=22^{\circ}$ is observed corresponding to diffusion phenomena in amorphous silica.

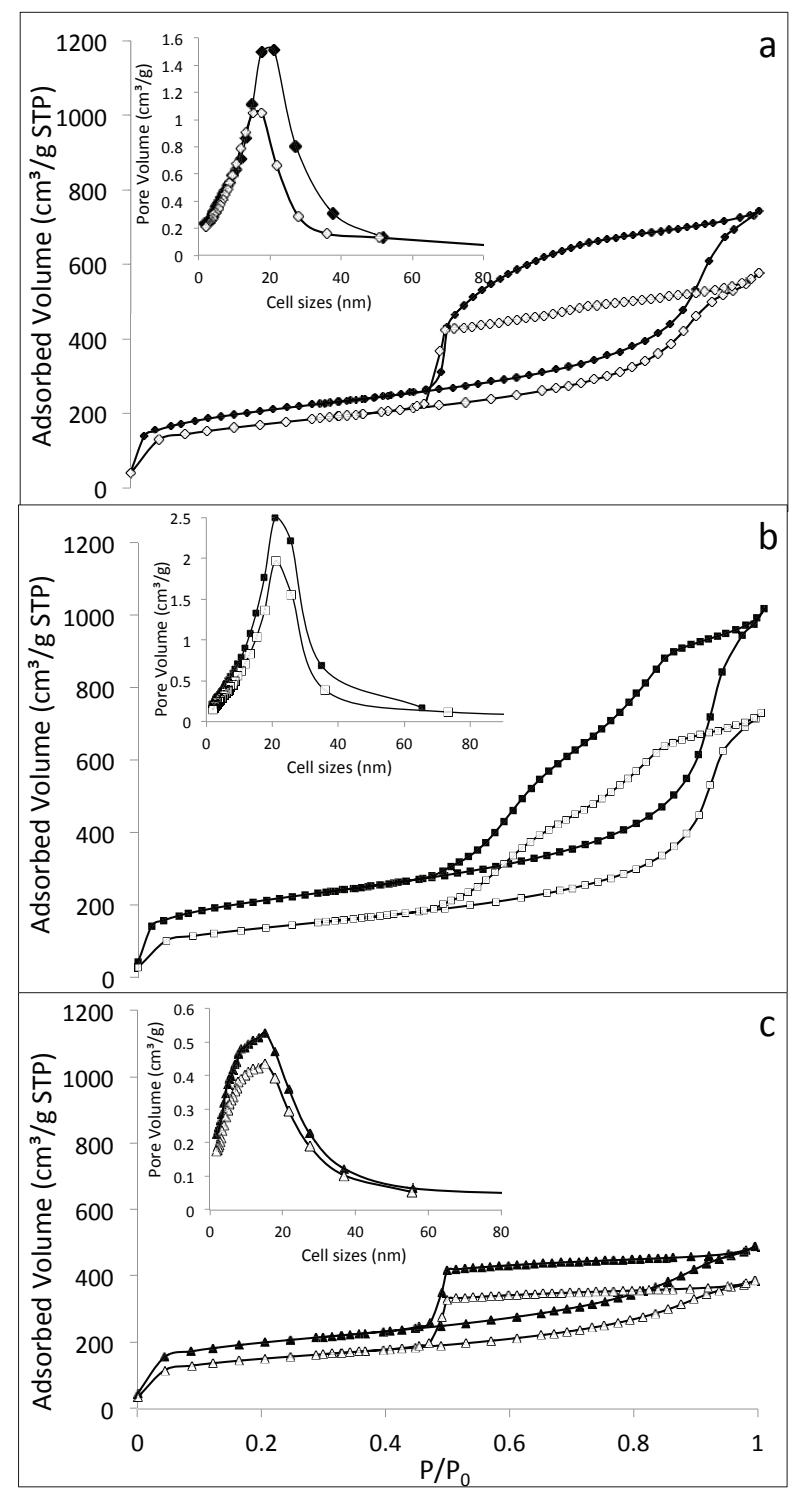

Fig. 2. $\mathrm{N}_{2}$ adsorption/desorption isotherms at $77 \mathrm{~K}$ and cell sizes distribution (from adsorption branch) for (a) : $\diamond) \mathrm{MCF},(\diamond) \mathrm{Ni}-\mathrm{MCF}$,

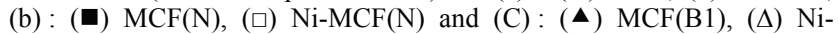
$\mathrm{MCF}(\mathrm{B} 1)$. 


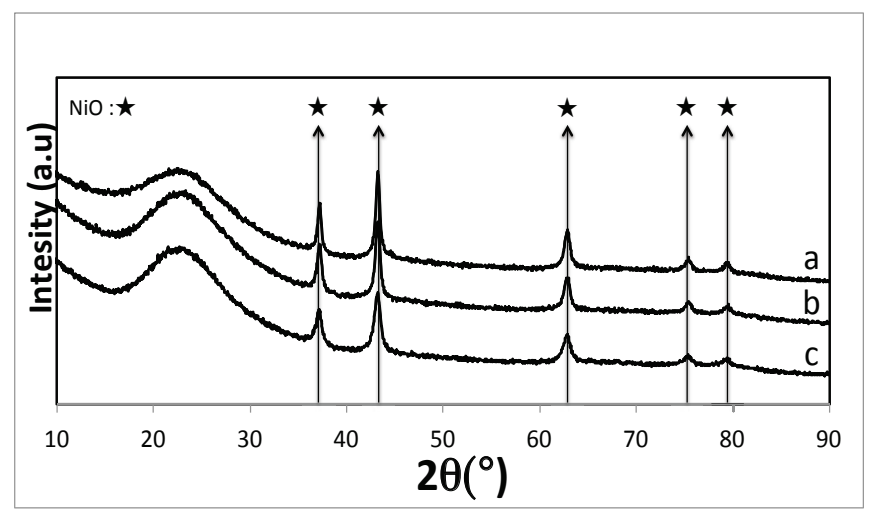

Fig. 3. XRD patterns of (a): $\operatorname{Ni-MCF}(\mathrm{N}),(b)$ : Ni-MCF, (c): Ni-MCF(B1) samples.

Five diffractograms peaks at $2 \theta=37,43,62,76$ and $80^{\circ}$ are also systematically seen and attributable to (111), (200), (220), (311) and (222) lattice planes of the face centered cubic structure of $\mathrm{NiO}$ oxide nanoparticles (JCPDS: 01-089-7130). The Scherrer formula was used to estimate the mean size of the NiO crystallites, assuming a spherical shape. The results are reported in Table II. With a $8.7 \mathrm{~nm}$ mean diameter, Ni$\operatorname{MCF}(\mathrm{N})$ is characterized by the smaller crystallites.

This size is inferior to the critical maximum value $(9 \mathrm{~nm})$ reported by Kawi et al [9] as providing good performances in DRM reaction. Hence, the nanoparticles in $\mathrm{Ni}-\mathrm{MCF}(\mathrm{N})$ could be used advantageously in the studied reaction. Conversely, it is commonly admitted that $\mathrm{Ni}$ metal particles having bigger size than the critical one are known to favor carbon deposition and hence enhance catalyst deactivation [9].

\section{Morphological properties}

Fig. 4. shows typical TEM images of $\mathrm{Ni}-\mathrm{MCF}(\mathrm{N})$ which was characterized by the best textural properties both before and after $\mathrm{Ni}$ addition. The images are consistent with an homogeneous organization of the support and reveal rather homogenous dispersion of the $\mathrm{NiO}$ nanoparticles. With low magnification, rather big Ni deposits seem to be present (Fig. 4A) but they consist in aggregates of small $\mathrm{Ni}$ nanoparticles with mean diameters below $10 \mathrm{~nm}$ (Fig. 4B, B'). Very small isolated nanoparticles are also seen everywhere in the material, as is examplified in Fig. 4C (wight circles) and in the associated zoomed image (Fig. 4C') which also highlights the pores. The particle sizes estimated from TEM are thus in good agreement with those deduced from XRD data (Table II).

TABLE II. NiO CRYSTALLITES SIZE DETERMINED FROM XRD DATA ANALYSIS

\begin{tabular}{|c|c|c|c|}
\hline Samples & Ni-MCF & Ni-MCF $(\mathbf{N})$ & Ni-MCF(B1) \\
\hline $\begin{array}{c}\text { Mean NiO particle } \\
\text { sizes (nm) }\end{array}$ & 11.2 & 8.7 & 11.7 \\
\hline
\end{tabular}

\section{Reducibility}

All calcined Ni-supports were reduced using $\mathrm{H}_{2}$ under $650^{\circ} \mathrm{C}$ to convert $\mathrm{NiO}$ to $\mathrm{Ni}^{0}$. TPR measurements were conducted in order to study the reducibility of deposited nickel in the calcined nickel mesocellular foams materials and indirectly its interaction with the support. Fig. 5 shows only one reduction peak per sample, centered at $405^{\circ} \mathrm{C}$ and $410^{\circ} \mathrm{C}$ for respectively Ni-MCF and Ni-MCF(B1), instead of $\sim 470^{\circ} \mathrm{C}$ for $\mathrm{Ni}-\mathrm{MCF}(\mathrm{N})$. Hence, both former samples behave similarly, whereas the occurrence of an $\mathrm{H}_{2}$ consumption at higher temperature would suggest a stronger interaction between $\mathrm{NiO}$ and the support in the case of $\mathrm{Ni}-\mathrm{MCF}(\mathrm{N})$. Nevertheless, peak surfaces are comparable for the three samples, in line with the similar Ni contents in all catalysts $(5 \mathrm{wt} \%)$. Note also that the reduction is achieved for all samples before $600^{\circ} \mathrm{C}$, confirming that the temperature of $650^{\circ} \mathrm{C}$ applied for in situ activation of the catalysts prior catalytic tests is appropriate for full metal reduction.

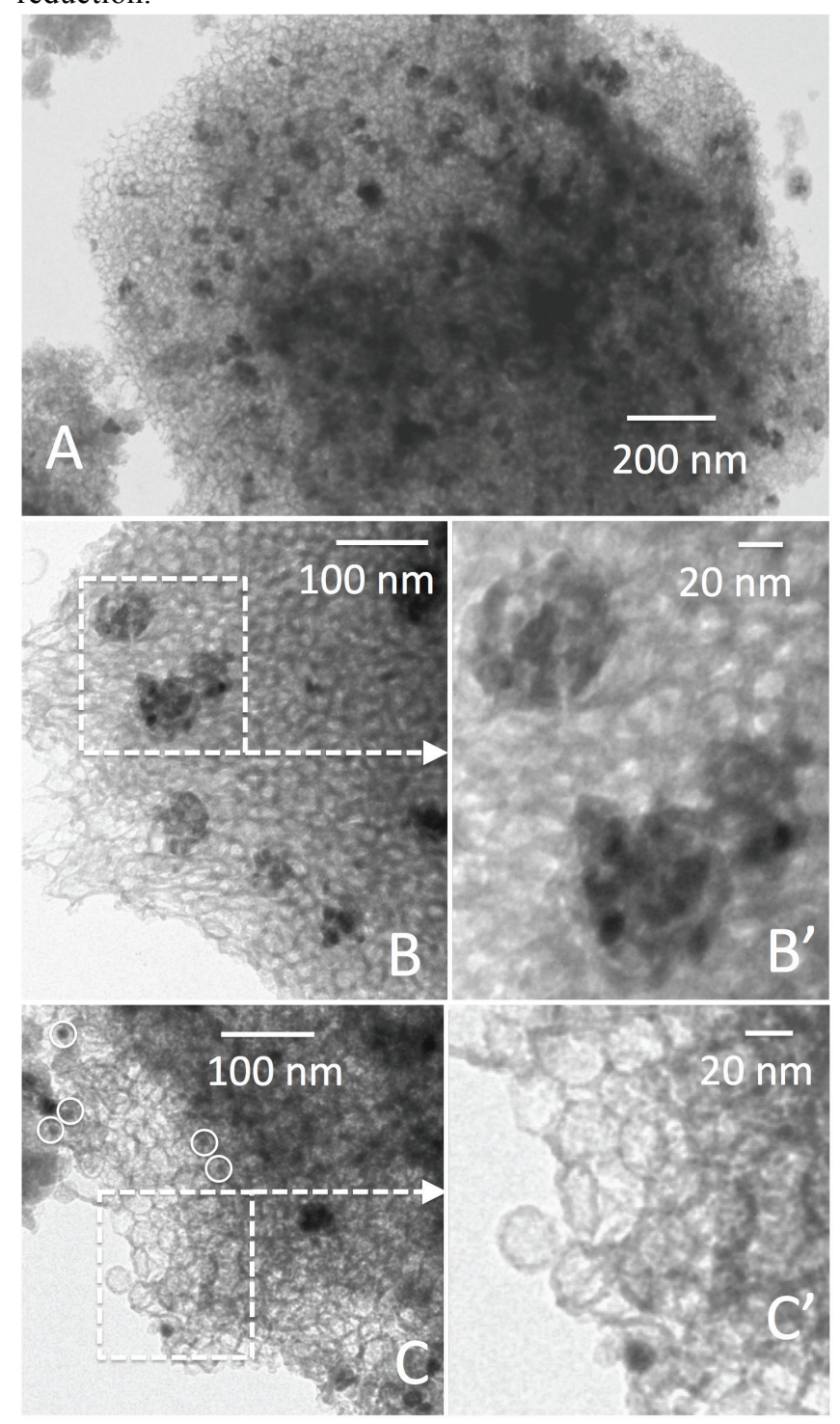

Fig. 4. TEM image of Ni-MCF(N) showing (A) a full grain and zones with (B) $\mathrm{Ni}$ aggregates or (C) isolated $\mathrm{Ni}$ nanoparticles. $\mathrm{B}^{\prime}$ and $\mathrm{C}^{\prime}$ are zoomed images of selected zones in B and C, respectively. 


\section{E. Catalytic performance in DRM}

The Ni-MCF, Ni-MCF(N) and Ni-MCF(B1) samples were tested in DRM from 200 to $800^{\circ} \mathrm{C}$. At low temperature, all catalysts are inactive, then the activity rises while increasing the temperature, in line with the endothermic nature of the reaction. Conversion of $\mathrm{CH}_{4}$ and $\mathrm{CO}_{2}$ vs. temperature are shown in Fig. 6, revealing significant differences in terms of catalytic performances between $\mathrm{Ni}-\mathrm{MCF}$, on one hand, and $\mathrm{Ni}-\mathrm{MCF}(\mathrm{N})$ and $\mathrm{Ni}-\mathrm{MCF}(\mathrm{B} 1)$, on the other hand.

By comparing the activity of the solids at $650^{\circ} \mathrm{C}, \mathrm{Ni}-\mathrm{MCF}$ showed the lower performances $\left(42 \% \mathrm{CH}_{4}\right.$ and $40 \% \mathrm{CO}_{2}$ conv.), while $\mathrm{Ni}-\mathrm{MCF}(\mathrm{B} 1)\left(67 \% \mathrm{CH}_{4}\right.$ and $75 \% \mathrm{CO}_{2}$ conv.) and $\mathrm{Ni}-\mathrm{MCF}(\mathrm{N})\left(67 \% \mathrm{CH}_{4}\right.$ and $68 \% \mathrm{CO}_{2}$ conv. $)$ showed very good results. For the best catalysts, the conversions are very close to the expected thermodynamic values (maximum possible conversions) estimated with carbon formation. Not only the reactants conversions but also the selectivity of the catalysts in given products, especially their ability to give the desired $\mathrm{H}_{2} / \mathrm{CO}$ ratio, is a very important criterion. Targeting the production of liquid fuels [12] for Fisher-Tropsch operations, a $\mathrm{H}_{2} / \mathrm{CO}=1$ is highly desirable. The values effectively obtained with the three selected materials are presented in Fig.7.

Hence, the less active Ni-MCF catalyst never gave the desired ratio, even at high temperature $\left(770^{\circ} \mathrm{C}\right)$. In contrast, $\mathrm{H}_{2} / \mathrm{CO}$ values very close to 1 were obtained with Ni-MCF(B1) at $650^{\circ} \mathrm{C}(0.98), 750^{\circ} \mathrm{C}(1.03)$ and $770^{\circ} \mathrm{C}(1.04)$ as well as with $\mathrm{Ni}-\mathrm{MCF}(\mathrm{N})$ at $750^{\circ} \mathrm{C}(1)$ and $770^{\circ} \mathrm{C}(1.01)$. As a whole, the $\mathrm{Ni-MCF}(\mathrm{N})$ sample turned out to gather a lot of advantages such as the best textural properties, the smallest $\mathrm{Ni}$ crystallites size, the highest reduction temperature and good activity and selectivity.

For these reasons, this material was selected for a study of the stability at $650^{\circ} \mathrm{C}$ during $4 \mathrm{~h}$ in flowing reactant gases as above (Fig. 8). shows that $\mathrm{Ni}-\mathrm{MCF}(\mathrm{N})$ is characterized by a really good stability vs. time at $650^{\circ} \mathrm{C}$, working very closely to the thermodynamic conditions (with carbon formation), i.e. with conversion rates of $\mathrm{CH}_{4}$ and $\mathrm{CO}_{2}$ equal to 60 and $71 \%$, respectively.

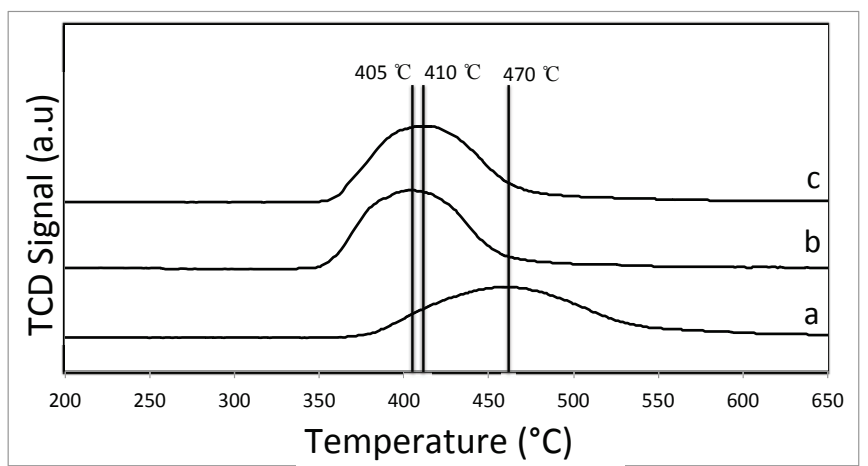

Fig. 5. Temperature programed reduction of: (a): $\mathrm{Ni}-\mathrm{MCF}(\mathrm{N}),(\mathrm{b})$ : Ni-MCF, (c): Ni-MCF(B1) samples.

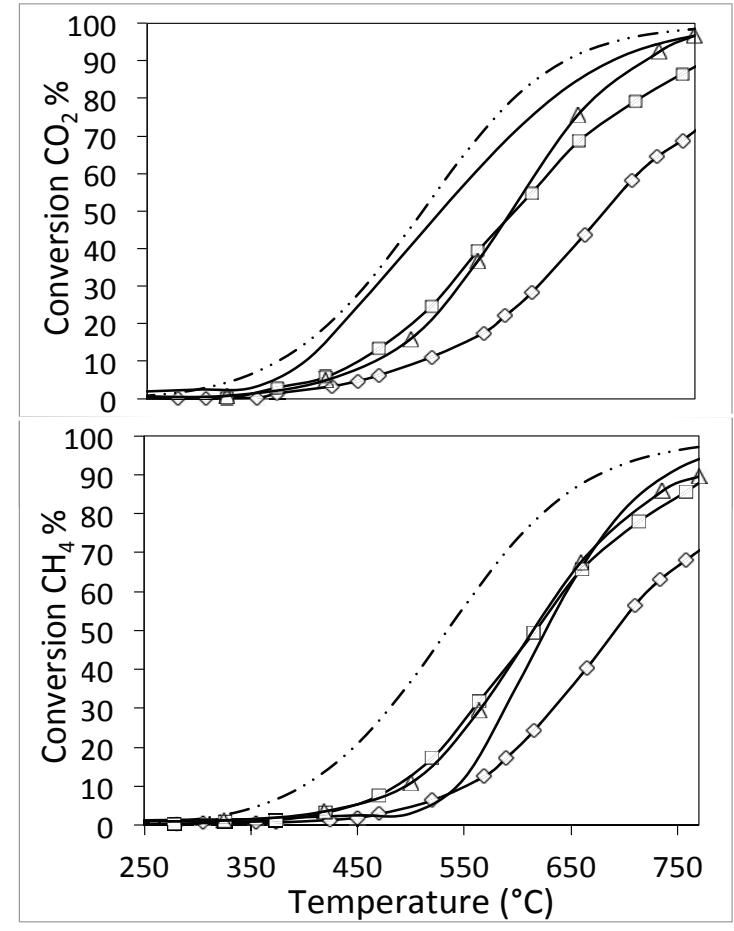

Fig. 6. Activity of reduced $(\diamond)$ : Ni-MCF, $(\square)$ : Ni-MCF(N) and $(\Delta)$ : Ni$\mathrm{MCF}(\mathrm{B} 1)$ in DRM. Thermodynamic curves with (-) and without (-..) carbon formation are also mentioned.

In addition, the XRD pattern (Fig. 9.) of $\mathrm{Ni}^{0}-\mathrm{MCF}(\mathrm{N})$ after use (spent catalyst) (a) is very similar to that after reduction (b), with three peaks at $2 \theta=44^{\circ}, 52^{\circ}$ and $76^{\circ}$ (JCPDS: 01-070-1849) characteristic of the $\mathrm{Ni}^{0}$ phase and width indicating crystallites size of $\sim 8.3 \mathrm{~nm}$ in both cases, thus emphasizing the absence of $\mathrm{Ni}$ sintering. In addition, the diffractogram of the spent catalyst did not reveal any presence of detectable structured carbon deposit, suggesting, if formed, that carbon phases remain limited.

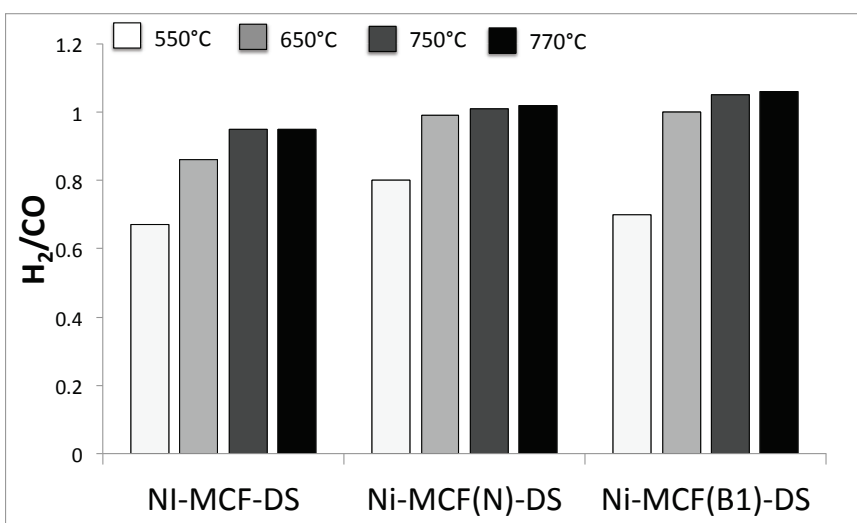

Fig. 7. $\mathrm{H}_{2} / \mathrm{CO}$ ratio vs temperature for $\mathrm{Ni}-\mathrm{MCF}, \mathrm{Ni}-\mathrm{MCF}(\mathrm{N})$ and $\mathrm{Ni}-$ $\mathrm{MCF}(\mathrm{B} 1)$ samples 


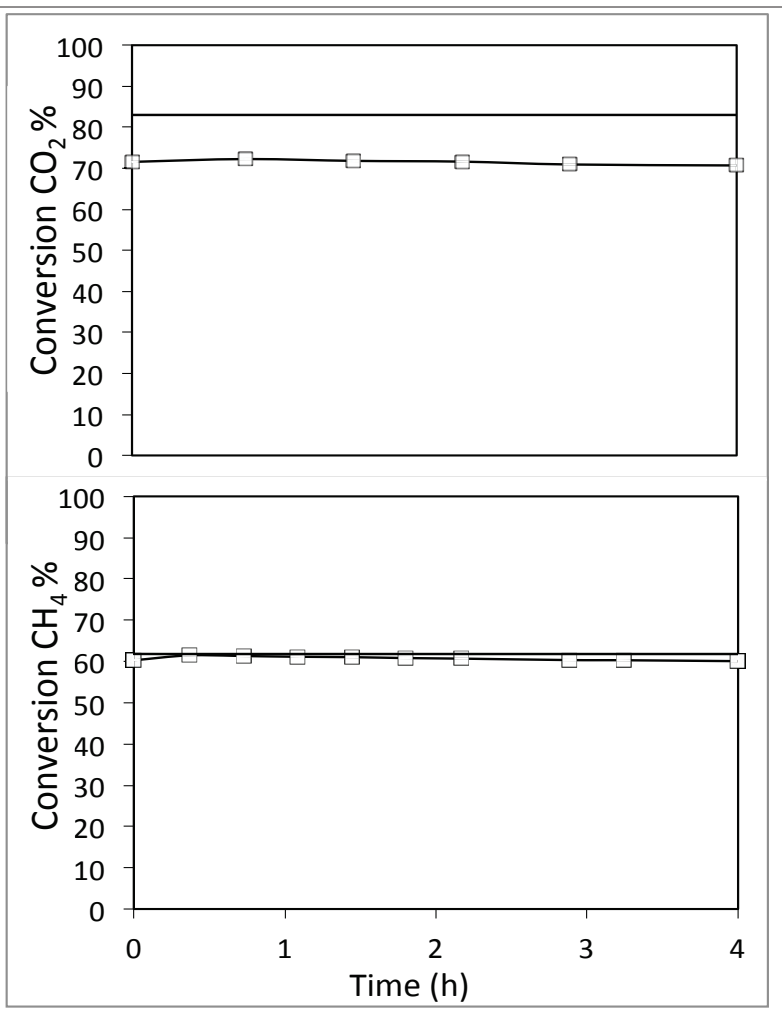

Fig. 8. Stability of $\mathrm{CO}_{2}$ and $\mathrm{CH}_{4}$ conversion in the presence of $\mathrm{Ni}-\mathrm{MCF}(\mathrm{N})$. $(\square)$. Thermodynamic curves with carbon formation (-) are also mentioned.

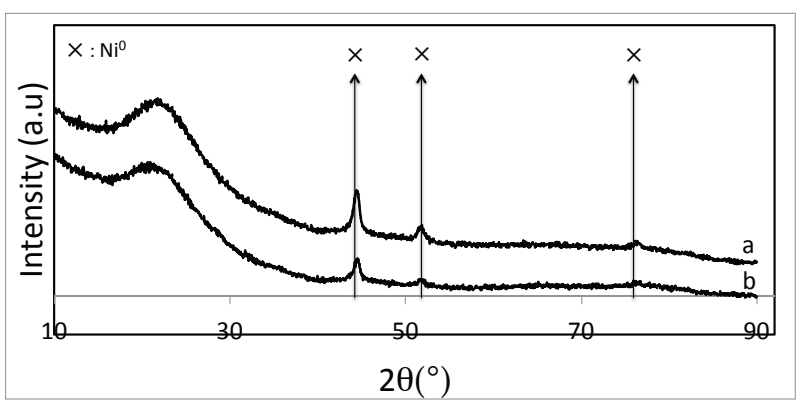

Fig. 9. XRD patterns for (a) spent $\mathrm{Ni}^{0}-\mathrm{MCF}(\mathrm{N})$ and (b) $\mathrm{Ni}^{0}-\mathrm{MCF}(\mathrm{N})$ after reduction.

\section{CONCLUSION}

Silica mesocellular foams (MCF) with different textural properties were synthesized and used as nickel supports for preparing dry methane reforming catalysts. Unlike what was expected, silica samples synthesized using butanol as a cosurfactant $(\mathrm{MCF}(\mathrm{B} 1)$ and $\mathrm{MCF}(\mathrm{B} 2)$ materials) did not display the optimal textural properties. The largest windows apertures, pores volumes and surface area were obtained with the $\mathrm{MCF}(\mathrm{N})$ support which synthesis involved $\mathrm{NH}_{4} \mathrm{~F}$. After nickel addition using the double-solvents method (post-synthesis) then activation, $\mathrm{Ni}-\mathrm{MCF}(\mathrm{N})$ also led to the best nickel support-interaction and best nickel dispersion. It also led to the best catalytic performances in terms of $\mathrm{CO}_{2}$ and $\mathrm{CH}_{4}$ conversions, close to maximum thermodynamic limitations and slightly above those obtained on the samples with MCF support synthesized in presence of n-butanol. Also, $\mathrm{Ni}-\mathrm{MCF}(\mathrm{N})$ was slightly more selective towards the production of syngas with a $\mathrm{H}_{2} / \mathrm{CO}$ ratio of 1 convenient for Fischer Tropsch. Compared to bibliography, those catalyst showed satisfying activity even slightly below that previously obtained on a $\mathrm{Ni}-\mathrm{SiO}_{2}$ catalyst with the same Ni content [12] Characterization data obtained on the spent catalyst agreed with very little carbon formation during the tests and the absence of metal active phase sintering.

\section{ACKNOWLEDGMENT}

The authors sincerely acknowledge the ERANETMED EUFP7 initiative and the national ANR (France) and CNRS-L (Lebanon) agencies for funding of SOL-CARE (Energy065) project (JC-ENERGY-2014 first call). Also, the authors thanks Sandra Casale (UPMC) for MET images and Hala Fallah (UOB) for XRD recorging.

\section{REFERENCES}

[1] W. Shan, W. Wang, and H. Ru, "Siliceous mesocellular foams modified via a partitioned cooperative self-assembly process using hexane as pore swelling agent." J. Non-Cryst. Solids, vol. 425, pp. 183-189, 2015.

[2] J. S. Lettow, Y. J. Han, P. Schmidt-Winkel, P. Yang, D. Zhao, G. D. Stucky and J. Y. Ying, "Hexagonal to Mesocellular Foam Phase Transition in Polymer-Templated Mesoporous Silicas," Langmuir, vol. 16, pp. 8291-8295, 2000.

[3] P. Schmidt-Winkel, C. J. Glinkas and G. D. Stucky, "Microemulsion Templates for Mesoporous Silica," Langmuir, vol. 16, pp. 356-361, 2000 .

[4] K. Szymanska, J. Bryjak, J. MrowiecbBialon, and A.B. Jarzebski, "Application and properties of siliceous mesostructured cellular foams as enzymes carriers to obtain efficient biocatalysts," Micropor. Mesopor. Mat, vol. 99, pp. 167-175, 2007.

[5] S. G. de Ávila, L. C. C. Silva and J. R. Matos, "Optimisation of SBA-15 properties using Soxhlet solvent extraction for template removal," Micropor. Mesopor. Mat, vol. 234, pp. 277-286, 2016.

[6] P. Y. Feng, X. Bu, G. D. Stucky, and D. J. Pine, "Monolithic Mesoporous Silica Templated by Microemulsion Liquid Crystals," J. Am. Chem. Soc, vol. 122, pp. 994-995, 2000.

[7] X. Zhou, A. Duan, Z. Zhao, Y. Gong, H. Wu, J. Li, Y. Wei, G. Jiang, J. Liu and Y. Zhang, "Synthesis of hierarchically porous silicas with mesophase transformations in a four-component microemulsion-type system and the catalytic performance for dibenzothiophene hydrodesulfurization," J. Mater. Chem. A 2, vol. 19, pp. 6823-6833, 2014.

[8] D. Pakhare and J. Spivey, " A review of dry $\left(\mathrm{CO}_{2}\right)$ reforming of methane over noble metal catalysts," Chem. Soc. Rev, vol. 43, pp. 7813-7837, 2014.

[9] S. Kawi, Y. Kathiraser, J. Ni, U. Oemar, Z. Li, and E. T. Saw, “Progress in Synthesis of Highly Active and Stable Nickel- Based Catalysts for Carbon Dioxide Reforming of Methane," ChemSusChem, vol. 8, pp. 3556-3575, 2015.

[10] J. van der Meer, I. Bardez-Giboire, C. Mercier, B. Revel, A. Davidson, and R. Denoyel," Mechanism of Metal Oxide Nanoparticle Loading in SBA-15 by the Double Solvent Technique," J. Phys. Chem. C, vol. 114, pp. 3507-3515, 2010.

[11] R. N. Widyaningrum, T. L. Church, M. Zhao, and A. T. Harris, "Mesocellular-foam-silica-supported Ni catalyst: Effect of pore size on $\mathrm{H}_{2}$ production from cellulose pyrolysis," Int. J. Hydrogen. Energ, vol. 37, pp. 9590-9601, 2012.

[12] M. N. Kaydouh, N. El Hassan, A. Davidson, S. Casale, and P. Massiani, "Highly active and stable N/SBA-15 catalysts prepared by a "two solvents" method for dry reforming of methane," Microp. Mesop. Mater, vol. 220, pp. 99-109, 2016. 